Journal of Engineering and Fundamentals

Vol. 2(2), pp. 30-41, December, 2015

Available online at http://www.tjef.net

ISSN: 2149-0325

http://dx.doi.org/10.17530/jef.15.14.2.2

\title{
Optimization of dry turning parameters on surface roughness and hardness of Austenitic Stainless steel (AISI316) by Taguchi Technique.
}

\author{
Rajendrakumar V. Kadi* \\ Department of Mechanical Engineering, Tontadarya College of Engineering, Gadag582101, \\ India.
}

\begin{abstract}
Suresh T. Dundur
Department of Industrial and Production Engineering, Basaveshwara Engineering College, Bagalkot 587101 India.
\end{abstract}

\begin{tabular}{|c|c|}
\hline Article history & Austenitic stainless steel, because of its excellent resistance to \\
\hline $\begin{array}{l}\text { Received: } \\
21.07 .2015\end{array}$ & $\begin{array}{l}\text { oxidation and corrosion, is found in variety of industrial } \\
\text { applications. Producing machined surfaces with good finish and }\end{array}$ \\
\hline $\begin{array}{l}\text { Received in revised form: } \\
03.09 .2015\end{array}$ & $\begin{array}{l}\text { wear resistance in those applications is a prime requirement, } \\
\text { especially when it is used in food and medical equipment. The }\end{array}$ \\
\hline $\begin{array}{l}\text { Accepted: } \\
04.09 .2015\end{array}$ & $\begin{array}{l}\text { present investigation is concerned with the determination of } \\
\text { optimal turning parameters for reduced roughness and increased }\end{array}$ \\
\hline Key words: & $\begin{array}{l}\text { hardness of the machined surfaces while turning austenitic stainless } \\
\text { steel } 316 \text { using carbide insert coated with TiN under dry condition. }\end{array}$ \\
\hline $\begin{array}{l}\text { austenitic stainless steel; CNC } \\
\text { turning; Taguchi technique; } \\
\text { surface roughness; } \\
\text { microhardness. }\end{array}$ & $\begin{array}{l}\text { Experimental trails were performed as per Taguchi's full factorial } \\
\text { design. To determine the optimum levels of control factors, the } \\
\text { statistical analysis for means (ANOM) based on S/N ratio was } \\
\text { used. Along with this, analysis of Variance (ANOVA) was carried } \\
\text { out to note those process parameters and their interactions that were } \\
\text { strongly contribute to the objective function. It is found that feed } \\
\text { rate plays a significant role in Ra and Rz values of surface } \\
\text { roughness, where as cut depth and interaction of speed and cut } \\
\text { depth have moderate effects. Speed and cut depth influence more } \\
\text { on Rz value compared to its Ra value. On the other hand, for } \\
\text { maximizing the hardness of the turned surface, joint effect of } \\
\text { turning speed and feed rate, and cut depth showed significant } \\
\text { effects. }\end{array}$ \\
\hline
\end{tabular}

*Correspondence: e-mail: rajendravk@yahoo.co.in 


\section{Introduction}

Austenitic stainless steel, because of its excellent resistance to oxidation and corrosion, is found in variety of industries such as marine, chemical, dairy, power and biomedical etc. [1, 4, 5, 9, and 10]. Therefore, Austenitic grade of stainless steel is among largest consumed steel which makes up to $70 \%$ of total stainless steel consumed worldwide [1, 8, 10, and 11]. However, machining of this hard to cut material is not that easy due to its high strength, poor surface finish, lower thermal conductivity, higher work hardening, high ductility, more micro structural and mechanical sensitivity to strain and strain rate, etc. [1-9]. As a result of it, this material induces rapid wear in cutting tools and tool wear related problems while machining. It is also found that addition of free cutting additives like lead, sulfur, selenium and tellurium increase the machinability of austenitic stainless steels, $[2,3]$.

Producing machined surfaces with good finish and resistance to wear are the prime requirements especially when Austenitic steel is used in medical equipment and food processing containers. Fine surface is also entailed for the improvement of tribological properties, corrosion resistance, fatigue strength, creep life and aesthetic appeal in the manufactured parts etc.[4, 8, and 12].Surface finish in particular is found to be affected by parameters like nose radius along with cutting speed, cutting depth and feed rate [13]. Machining at lower speeds has a tendency to form built up edge causing increased surface roughness. But the formation of built up edge can be avoided by choosing higher cutting speeds [4].Ibrahim Ciftci [7] while machining austenitic stainless steel with cemented carbide inserts having multiple coatings of TiN observed that, increase in cutting velocity initially reduces the surface roughness till it reaches a lower value and then it increases. A general consensus prevails amongst the investigators regarding predominance of cutting speed and feed rate amongst all those factors influencing roughness of machined surface [10, 15 and 16]. However, in contrast to it few investigators such as Kaladhar et al. [8] and Dilbag Singh and VenkateswaraRao [13] identified that, after the feed rate next most predominant factors are nose radius, rake angle and cutting velocity. From the literature it can be revealed that substantial work has been carried out in analyzing the cause of machining parameters on roughness of the turned surface but, little focus on wear resistance and the micro-hardness of machined subsurface. Therefore, the main intention of this investigation is to find the optimal turning parameters( speed, feed and cut depth) for the combined effect of surface roughness and micro hardness of the turned surfaces while machining austenitic stainless steel 316 with TiN-coated carbide insert.

Taguchi's full factorial design $\left(\mathrm{L}_{27}\right)$ orthogonal array has been used to achieve the above objective. And also, a numerical analysis (ANOVA) has been performed to know which process variables and their interactions are statistically important. Finally, ANOM is done to find the optimum level of each variable for both surface roughness $\left(\mathrm{R}_{\mathrm{a}}\right.$ and $\left.\mathrm{R}_{\mathrm{z}}\right)$ and microhardness, and results are compared with the experimental values. Statistical package MINITAB was used to perform the statistical analysis.

\section{Methodology}

The present study is carried out using Taguchi's full factorial design. This method makes use of orthogonal arrays for optimizing the responses. The orthogonal arrays consider simultaneously the effect of many controlling factors on the response quantity. The orthogonal experiments were conducted to obtain the optimum level for every controlling factor. Further these experiments provide 
information about effect of individual parameters and interactive effect of the on response[18, 19].

In this optimization technique objective function is formed on the basis of "signal to noise (S/N) ratio" which is subjected to the constraints formed by the noise factors using orthogonal matrix.[18, 19]. Thus Taguchi method gives the expected optimal performance under the noise factors. Based on the nature of variable i.e. $\mathrm{S} / \mathrm{N}$ values ratios, the objective function can be selected as to "smaller the better", "larger the better" and "nominal the best" type. ANOM of S/N ratio helps in determining the admirable combination of controlling parameters and their levels. The ANOVA helps in understanding the individual and interactive effect of control factors on the responses $[18,19]$.

\section{Experimentation:}

In the present investigation, cylindrical turning trails were carried out as per the full factorial $\left(3^{3}\right)$ design matrix, a whole of 27 trials, all having a unique combination of every levels of factors were carried out. Three control factors namely cutting speed, cut depth and feed rate are chosen as control factors for the present study. The different levels of cutting parameters are decided in accordance with the tool manufacturer's recommendation for the given material used in the experiments. Each controlling factors is considered at three levels and are illustrated in Table 1. According to Taguchi's full factorial design method, $\mathrm{L}_{27}$ orthogonal array was used in the design of experiment. Table 2 gives the detailed outline of experimentation. The $\mathrm{CNC}$ lathe machine with Fanuc control $(11 \mathrm{~kW}$ with spindle speed up to $4000 \mathrm{rpm}$ ) was used to conduct the turning trails in dry condition. The work material used in the experiment is round bar of $32 \mathrm{~mm}$ diameter Austenitic Stainless Steel AISI316 and Table 3 gives detail composition of it.

Table1. Control factors with chosen levels.

\begin{tabular}{|l|l|c|c|c|}
\hline \multirow{2}{*}{ Code } & \multirow{2}{*}{ Control Factor } & \multicolumn{3}{|c|}{ Level } \\
\cline { 3 - 5 } & & 1 & 2 & 3 \\
\hline A & Speed, M/min & 120 & 150 & 180 \\
\hline B & Feed, $\mathrm{mm} / \mathrm{rev}$ & 0.20 & 0.25 & 0.30 \\
\hline C & Cut depth, mm & 0.5 & 1.0 & 1.5 \\
\hline
\end{tabular}

Table 2. Full Factorial Array $\left(\mathrm{L}_{27}\right)$, measured response and corresponding $\mathrm{S} / \mathrm{N}$ ratios.

\begin{tabular}{|c|c|c|c|c|c|c|c|c|c|}
\hline $\begin{array}{c}\text { Trail } \\
\text { No }\end{array}$ & $\begin{array}{c}\text { Speed, } \\
\mathbf{A}\end{array}$ & $\begin{array}{c}\text { Feed, } \\
\mathbf{B}\end{array}$ & $\begin{array}{c}\mathbf{C u t} \\
\mathbf{d e p t h}, \mathbf{C}\end{array}$ & $\begin{array}{c}\mathbf{R}_{\mathbf{a}} \\
(\boldsymbol{\mu \mathbf { m } )}\end{array}$ & $\begin{array}{c}\mathbf{R}_{\mathbf{z}} \\
(\boldsymbol{\mu} \mathbf{m})\end{array}$ & $\begin{array}{c}\text { Hardness, } \\
\mathbf{H}(\mathbf{H v})\end{array}$ & $\begin{array}{c}\text { S/N Ration } \\
\text { For } \mathbf{R}_{\mathbf{a}} \\
\boldsymbol{\eta}_{\mathbf{1}}(\mathbf{d B})\end{array}$ & $\begin{array}{c}\text { S/N Ration } \\
\text { for }_{\mathbf{z}} \\
\boldsymbol{\eta}_{\mathbf{2}}(\mathbf{d B})\end{array}$ & $\begin{array}{c}\text { S/N Ration for } \\
\text { Micro Hardness } \\
\left.\boldsymbol{\eta}_{\mathbf{3}} \mathbf{( d B}\right)\end{array}$ \\
\hline 01 & 120 & 0.20 & 0.5 & 2.332 & 10.884 & 248 & -7.3546 & -20.7358 & 47.8890 \\
\hline 02 & 120 & 0.20 & 1.0 & 2.538 & 12.112 & 272 & -8.0898 & -21.6643 & 48.6914 \\
\hline 03 & 120 & 0.20 & 1.5 & 3.026 & 14.566 & 288 & -9.6174 & -23.2668 & 49.1878 \\
\hline 04 & 120 & 0.25 & 0.5 & 3.584 & 14.922 & 291 & -11.0874 & -23.4765 & 49.2779 \\
\hline 05 & 120 & 0.25 & 1.0 & 3.736 & 17.152 & 315 & -11.4481 & -24.6863 & 49.9662 \\
\hline 06 & 120 & 0.25 & 1.5 & 3.832 & 18.208 & 341 & -11.6685 & -25.2052 & 50.6551 \\
\hline 07 & 120 & 0.30 & 0.5 & 4.582 & 18.838 & 335 & -13.2211 & -25.5007 & 50.5009 \\
\hline 08 & 120 & 0.30 & 1.0 & 4.272 & 18.876 & 297 & -12.6126 & -25.5182 & 49.4551 \\
\hline 09 & 120 & 0.30 & 1.5 & 3.832 & 20.258 & 331 & -11.6685 & -26.1319 & 50.3966 \\
\hline
\end{tabular}




\begin{tabular}{|l|l|l|l|l|l|l|l|l|l|}
\hline 10 & 150 & 0.20 & 0.5 & 2.378 & 10.726 & 322 & -7.5242 & -20.6088 & 50.1571 \\
\hline 11 & 150 & 0.20 & 1.0 & 2.632 & 13.278 & 315 & -8.4057 & -22.4627 & 49.9662 \\
\hline 12 & 150 & 0.20 & 1.5 & 2.068 & 12.228 & 328 & -6.3110 & -21.7471 & 50.3175 \\
\hline 13 & 150 & 0.25 & 0.5 & 3.510 & 15.236 & 297 & -10.9061 & -23.6574 & 49.4551 \\
\hline 14 & 150 & 0.25 & 1.0 & 3.324 & 16.262 & 330 & -10.4332 & -24.2235 & 50.3703 \\
\hline 15 & 150 & 0.25 & 1.5 & 2.610 & 12.124 & 375 & -8.3328 & -21.6729 & 51.4806 \\
\hline 16 & 150 & 0.30 & 0.5 & 4.418 & 17.742 & 305 & -12.9045 & -24.9801 & 49.6860 \\
\hline 17 & 150 & 0.30 & 1.0 & 3.978 & 18.000 & 312 & -11.9933 & -25.1055 & 49.8831 \\
\hline 18 & 150 & 0.30 & 1.5 & 3.020 & 14.622 & 335 & -9.6001 & -23.3001 & 50.5009 \\
\hline 19 & 180 & 0.20 & 0.5 & 3.284 & 14.872 & 288 & -10.3281 & -23.4474 & 49.1878 \\
\hline 20 & 180 & 0.20 & 1.0 & 2.592 & 13.688 & 292 & -8.2727 & -22.7268 & 49.3077 \\
\hline 21 & 180 & 0.20 & 1.5 & 1.664 & 10.300 & 378 & -4.4231 & -20.2567 & 51.5498 \\
\hline 22 & 180 & 0.25 & 0.5 & 3.460 & 14.342 & 273 & -10.7815 & -23.1322 & 48.7233 \\
\hline 23 & 180 & 0.25 & 1.0 & 3.630 & 19.068 & 257 & -11.1981 & -25.6061 & 48.1987 \\
\hline 24 & 180 & 0.25 & 1.5 & 1.420 & 07.734 & 272 & -3.0458 & -17.7681 & 48.6914 \\
\hline 25 & 180 & 0.30 & 0.5 & 4.380 & 17.766 & 292 & -12.8295 & -24.9918 & 49.3077 \\
\hline 26 & 180 & 0.30 & 1.0 & 4.886 & 21.332 & 339 & -13.7791 & -26.5806 & 50.6040 \\
\hline 27 & 180 & 0.30 & 1.5 & 3.328 & 15.374 & 359 & -10.4437 & -23.7357 & 51.1019 \\
\hline
\end{tabular}

Table 3. Chemical Composition of austenitic stainless steel AISI 316.

\begin{tabular}{|c|c|c|c|c|c|c|c|c|c|c|c|c|c|c|}
\hline Elements & C & $\mathrm{Si}$ & Mn & $\mathbf{S}$ & $\mathbf{P}$ & $\mathrm{Cr}$ & $\mathrm{Ni}$ & Mo & cu & Co & $\mathbf{T i}$ & V & $\mathrm{Nb}$ & $\mathrm{Fe}$ \\
\hline & 0.058 & 0.349 & 1.080 & 0.019 & 0.013 & 16.536 & 10.769 & 2.086 & 0.559 & 0.079 & 0.009 & 0.014 & 0.020 & 68.319 \\
\hline
\end{tabular}

The carbide inserts with CVD coating of TiN (CNMG 120416) having integrated chip breaker were used during the experiment. The tool having combination of tungsten carbide as base matrix and $\mathrm{TiN}$ as a coating material, exhibit the properties of high thermal resistance and low frictional coefficient. This makes the tool to become ideal for dry turning of hard to

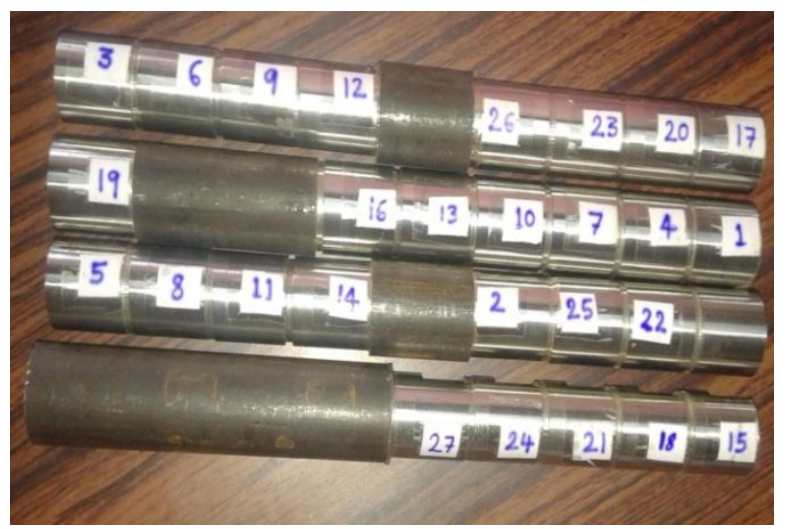

Fig.1 Work material labeled with experiment numbers. cut materials. A square shank tool holder with ISO specification of GCLNR2020 K12 was used during machining. Straight turning trails were done on specimen for the length of 30 $\mathrm{mm}$ each for every combination of three parameters with three levels which is shown in Fig1. Fig.2 depicts the experimental setup.

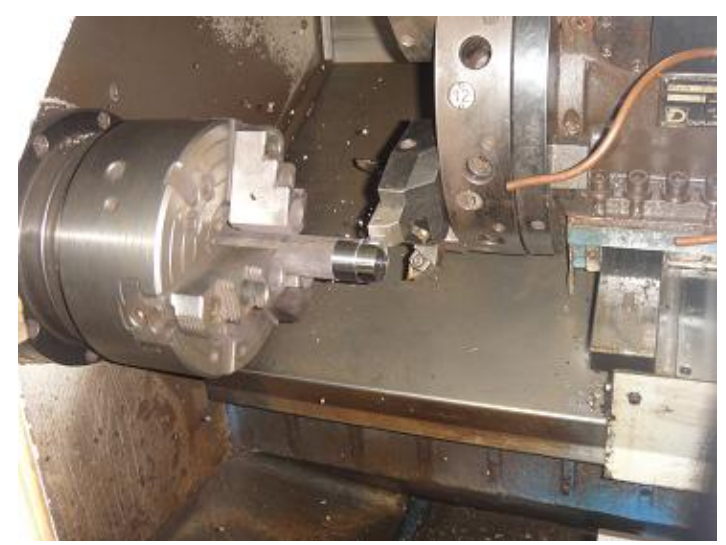

Fig.2Experimental setup for CNC turning. 
The measured surface roughness and microhardness were considered to assess the surface quality and wear resistance of turned surface respectively. The Mitutoyo Surf Test model 'SJ-201' was employed to determine the values of surface roughness at five various locations around the turned surface to reduce the error. A cut-off length of $0.8 \mathrm{~mm}$ for the 5 samples was chosen during the measurement. The mean values of $R_{a}$ and $R_{z}$ were used for the analysis of surface roughness. The microhardness of every specimen was determined by using low load Vickers hardness tester (Technosys, $0.2-5 \mathrm{Kg}$ with $40 \mathrm{X}$ magnification) and is illustrated in fig.3.

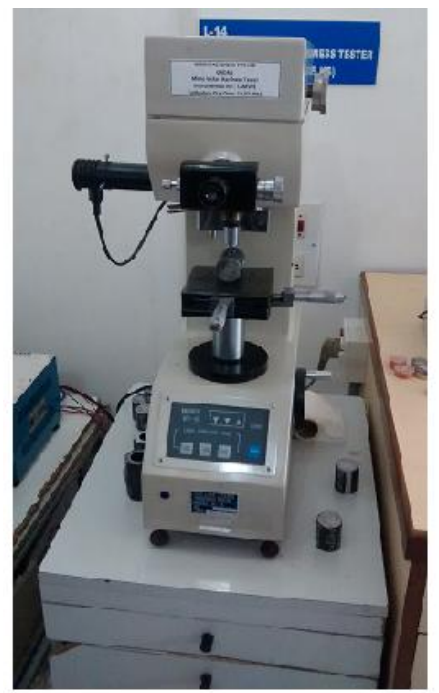

Fig.3 Vickers hardness tester.

\section{Results and Discussion ANOM and ANOVA}

The present investigation on dry turning, roughness of the machined surface is to be smaller and the hardness is to be larger. To attain this $\mathrm{S} / \mathrm{N}$ ratio for all runs of the orthogonal array is given by:

$$
\begin{gathered}
\eta_{1}=-10 \log _{10}\left(R_{a}{ }^{2}\right) \\
\eta_{2}=-10 \log _{10}\left(R_{z}{ }^{2}\right) \\
\eta_{3}=-10 \log _{10}\left(H^{-2}\right)
\end{gathered}
$$

The successive $\mathrm{S} / \mathrm{N}$ ratios for all the runs of $\mathrm{L}_{27}$ are depicted in Table 2. To arrive at control factors with the optimum levels, ANOM based on $\mathrm{S} / \mathrm{N}$ ratio was used and summery of which is illustrated in Table 4, 5 and 6 . The level of control factor having greatest $\mathrm{S} / \mathrm{N}$ ratio is the optimum level. For minimum surface roughness the set of optimum control factors for $R_{a}$ value 2 is $A 3, B 1$ and $C 3$ and for $R_{z}$ value $\mathrm{A} 2$, B1 and C3. Similarly for maximum hardness of turned surface, control factors with best levels are found to be A2, B3 and C3.

Table 4. Optimum level of $\mathrm{R}_{\mathrm{a}}$ Value using ANOM

\begin{tabular}{|c|c|c|c|c|}
\hline \multirow{2}{*}{$\begin{array}{c}\text { Parameter } \\
\text { Code }\end{array}$} & \multicolumn{3}{|c|}{ Levels } & \multirow{2}{*}{$\begin{array}{c}\text { Optimum } \\
\text { Level }\end{array}$} \\
\cline { 2 - 4 } & 1 & 2 & 3 & 3 \\
\hline A & -10.752 & -9.601 & -9.456 & 1 \\
\hline B & -7.814 & -9.878 & -12.117 & 3 \\
\hline C & -10.771 & -10.693 & -8.346 & \\
\hline
\end{tabular}


Table 5. Optimum level of $\mathrm{R}_{\mathrm{z}}$ Value using ANOM.

\begin{tabular}{|c|c|c|c|c|}
\hline \multirow{2}{*}{$\begin{array}{c}\text { Parameter } \\
\text { code }\end{array}$} & \multicolumn{3}{|c|}{ Levels } & \multirow{2}{*}{$\begin{array}{c}\text { Optimum } \\
\text { Level }\end{array}$} \\
\cline { 2 - 4 } & 1 & 2 & 3 & 2 \\
\hline A & -24.02 & -23.08 & -23.14 & 1 \\
\hline B & -21.88 & -23.27 & -25.09 & 3 \\
\hline C & -23.39 & -24.29 & -22.56 & \\
\hline
\end{tabular}

Table 6.S/N ratio based ANOM for Micro hardness

\begin{tabular}{|c|c|c|c|c|}
\hline \multirow{2}{*}{$\begin{array}{c}\text { Parameter } \\
\text { code }\end{array}$} & \multicolumn{3}{|c|}{ Levels } & Optimum \\
\cline { 2 - 4 } & 1 & 2 & 3 & \\
\hline A & 49.56 & 50.20 & 49.63 & 2 \\
\hline B & 49.58 & 49.65 & 50.16 & 3 \\
\hline C & 49.35 & 49.60 & 50.43 & 3 \\
\hline
\end{tabular}

To know the relative contribution of every control factors, ANOVA based on S/N ratio has been used $[18,19]$ and Tables 7,8 and 9 represent these results. It can be observed from ANOVA Table that, for $R_{a}$ value of surface roughness feed rate $(45.69 \%)$ plays an important role where as cut depth $(18.74 \%)$ and combined effect of speed and cut depth (17.14\%) have slight effect. Similarly for $R_{z}$ value of surface roughness again feed rate
(41.87\%) has its highest contribution and interactive effect of speed and cut depth $(23.38 \%)$ has its noticeable effect. On the other hand, for maximizing the hardness of the turned surface, interaction of speed and feed $(36.42 \%)$ and cut depth $(25.23 \%)$ play significant effect, whereas cutting speed and feed rate do not affect significantly in increasing microhardness.

Table 7. S/N ratio based ANOVA for $\mathrm{R}_{\mathrm{a}}$ value.

\begin{tabular}{|c|c|c|c|c|}
\hline $\begin{array}{c}\text { Parameter } \\
\text { Code }\end{array}$ & $\begin{array}{c}\text { Degree of } \\
\text { Freedom }\end{array}$ & $\begin{array}{c}\text { Sum of } \\
\text { squares }\end{array}$ & $\begin{array}{c}\text { Mean } \\
\text { square }\end{array}$ & $\begin{array}{c}\% \\
\text { Contribution }\end{array}$ \\
\hline $\mathrm{A}$ & 2 & 9.077 & 4.5387 & 4.97 \\
\hline $\mathrm{B}$ & 2 & 83.362 & 41.6810 & 45.69 \\
\hline $\mathrm{C}$ & 2 & 34.186 & 17.0928 & 18.74 \\
\hline $\mathrm{A} * \mathrm{~B}$ & 4 & 8.128 & 2.0321 & 4.45 \\
\hline $\mathrm{A} * \mathrm{C}$ & 4 & 31.265 & 7.8162 & 17.14 \\
\hline $\mathrm{B} * \mathrm{C}$ & 4 & 3.143 & 0.7858 & 1.72 \\
\hline Error & 8 & 13.294 & 1.6617 & 7.29 \\
\hline Total & 26 & 182.455 & 75.6083 & 100 \\
\hline
\end{tabular}

Table 8. S/N ratio based ANOVA for $R_{z}$ value.

\begin{tabular}{|c|c|c|c|c|}
\hline $\begin{array}{c}\text { Parameter } \\
\text { Code }\end{array}$ & $\begin{array}{c}\text { Degree of } \\
\text { Freedom }\end{array}$ & $\begin{array}{c}\text { Sum of } \\
\text { squares }\end{array}$ & $\begin{array}{c}\text { Mean } \\
\text { square }\end{array}$ & $\begin{array}{c}\% \\
\text { Contribution }\end{array}$ \\
\hline $\mathrm{A}$ & 2 & 4.975 & 2.487 & 4.45 \\
\hline $\mathrm{B}$ & 2 & 46.774 & 23.387 & 41.87 \\
\hline
\end{tabular}




\begin{tabular}{|c|c|c|c|c|}
\hline $\mathrm{C}$ & 2 & 13.335 & 6.668 & 11.94 \\
\hline $\mathrm{A} * \mathrm{~B}$ & 4 & 5.702 & 1.426 & 5.11 \\
\hline $\mathrm{A} * \mathrm{C}$ & 4 & 26.115 & 6.529 & 23.38 \\
\hline $\mathrm{B} * \mathrm{C}$ & 4 & 6.514 & 1.629 & 5.83 \\
\hline Error & 8 & 8.290 & 1.036 & 7.42 \\
\hline Total & 26 & 111.705 & 43.162 & 100 \\
\hline
\end{tabular}

Table 9. $\mathrm{S} / \mathrm{N}$ ratio based ANOVA for Micro Hardness.

\begin{tabular}{|c|c|c|c|c|}
\hline $\begin{array}{c}\text { Parameter } \\
\text { Code }\end{array}$ & $\begin{array}{c}\text { Degree of } \\
\text { Freedom }\end{array}$ & $\begin{array}{c}\text { Sum of } \\
\text { squares }\end{array}$ & $\begin{array}{c}\text { Mean } \\
\text { square }\end{array}$ & $\begin{array}{c}\% \\
\text { Contribution }\end{array}$ \\
\hline $\mathrm{A}$ & 2 & 2.2406 & 1.12029 & 9.88 \\
\hline $\mathrm{B}$ & 2 & 1.7960 & 0.89798 & 7.92 \\
\hline $\mathrm{C}$ & 2 & 5.7209 & 2.86045 & 25.23 \\
\hline $\mathrm{A} * \mathrm{~B}$ & 4 & 8.2533 & 2.06332 & 36.42 \\
\hline $\mathrm{A} * \mathrm{C}$ & 4 & 0.2533 & 0.06334 & 1.12 \\
\hline $\mathrm{B} * \mathrm{C}$ & 4 & 0.1868 & 0.04670 & 0.82 \\
\hline Error & 8 & 4.2201 & 0.52752 & 18.61 \\
\hline Total & 26 & 22.6710 & 7.57960 & 100 \\
\hline
\end{tabular}

For predicting and confirming the projected output based on the greatest combined effect of control factors, the predicted Taguchi's signal to noise ratio $\left(\eta_{\text {opt }}\right)$ is obtained from $[18,19]$ :

$\eta_{\text {opt }}=\mathrm{m}+\sum_{\mathrm{j}=1}^{\mathrm{p}}\left[\left(\mathrm{m}_{\mathrm{i}, \mathrm{j}}\right)_{\max }-\mathrm{m}\right]$

Where, $\left(m_{i, j}\right)_{\max }$ is the $\mathrm{S} / \mathrm{N}$ ratio of the best combination $i^{\text {th }}$ level with $j^{\text {th }}$ factor for $\mathrm{p}^{\text {th }}$ main design factor. The quality characteristic of the experiments conducted for the conformation of methodology is expressed by the confidence interval (CI). It is determined by using the following relation [19]:

$\mathrm{CI}=\sqrt{F_{\left(1, \gamma_{e}\right)} V_{e}\left(\frac{1}{\eta_{\text {eff }}}+\frac{1}{\eta_{\text {ver }}}\right)}$

where $F_{\left(1, \gamma_{e}\right)}$ is the $\mathrm{F}$ value for $95 \% \mathrm{CI}, \gamma_{e}$ is the degree of freedom for error, $V_{e}$ is the variance for error, $\eta_{e f f}=\frac{N}{1+\gamma} ; \mathrm{N}=$ Total number of trials in orthogonal array and $\gamma=$ degree of freedom of main control factor and $\eta_{v e r}$ is number of validation test trials taken. This confidence interval is determined to witness the proximity of the observed value $\left(\eta_{o b s}\right)$ to that of predicted value $\left(\eta_{\text {opt }}\right)$.

Table10 shows the results of validation tests and it reveals that the predicted error i.e., $\left(\eta_{o p t}-\eta_{o b s}\right)$ is within confidence interval value. Thus, Taguchi technique was used to optimize the surface roughness and micro hardness with a 0.05 significance level. The optimum level of control factors that reduce the surface roughness and increase the surface hardness are presented in Table 11.

Table 10. Test report of confirmation experiments.

\begin{tabular}{|c|c|c|c|}
\hline Performance measures & $\mathbf{R}_{\mathrm{a}}$ & $\mathbf{R}_{\mathrm{z}}$ & Hardness \\
\hline Levels $(\mathrm{A}, \mathrm{B}, \mathrm{C})$ & $3,1,3$ & $2,1,3$ & $2,3,3$ \\
\hline $\mathrm{S} / \mathrm{N}$ predicted $\left(\eta_{\mathrm{opt}}\right), \mathrm{dB}$ & -5.74311 & -20.6933 & 51.19889 \\
\hline Observed value & $1.664 \mu \mathrm{m}$ & $12.228 \mu \mathrm{m}$ & $335 \mathrm{Hv}$ \\
\hline
\end{tabular}




\begin{tabular}{|c|c|c|c|}
\hline $\mathrm{S} / \mathrm{N}$ observed $\left(\eta_{\mathrm{obs}}\right), \mathrm{dB}$ & -4.4231 & -21.7471 & 50.5009 \\
\hline Prediction error, dB & -1.32001 & 1.0538 & 0.69799 \\
\hline Confidence interval value $(\mathrm{CI}), \mathrm{dB}$ & \pm 1.876208 & \pm 1.807246 & \pm 1.289606 \\
\hline
\end{tabular}

Table 11. Optimal combination of control factors with optimal values of out puts.

\begin{tabular}{|l|c|c|c|c|}
\hline \multirow{2}{*}{ Response } & \multicolumn{4}{|c|}{ Optimal combination of input variable } \\
\cline { 2 - 5 } & $\begin{array}{c}\text { Speed } \\
(\mathrm{m} / \mathrm{min})\end{array}$ & $\begin{array}{c}\text { Feed } \\
(\mathrm{mm} / \mathrm{rev})\end{array}$ & $\begin{array}{c}\text { Cut depth } \\
(\mathrm{mm})\end{array}$ & Optimal value \\
\hline Surface roughness $\left(\mathrm{R}_{\mathrm{a}}\right)$ & 180 & 0.20 & 1.5 & $1.664 \mu \mathrm{m}$ \\
\hline Surface roughness $\left(\mathrm{R}_{\mathrm{z}}\right)$ & 150 & 0.20 & 1.5 & $12.228 \mu \mathrm{m}$ \\
\hline Hardness & 150 & 0.30 & 1.5 & 335 \\
\hline
\end{tabular}

\section{Effects of cutting parameters}

To determine the effect of cutting parameters on surface roughness $\left(\mathrm{R}_{\mathrm{a}}\right.$ and $\mathrm{R}_{\mathrm{z}}$ ) and surface hardness during dry turning direct main effect plots are drawn using MINITAB 16 software [20].

\section{Analysis of surface profile}

The main effect of cutting parameters on surface profile when they change from the minimum to maximum levels

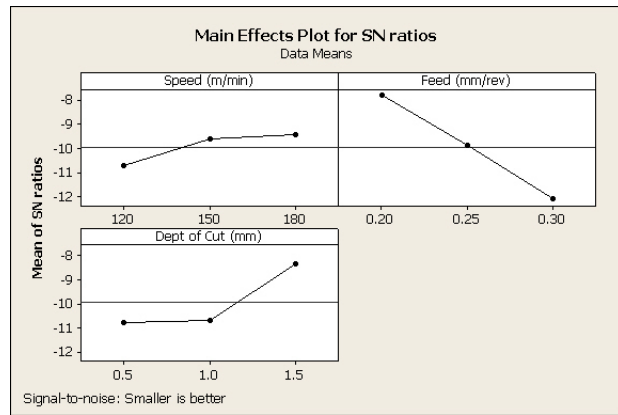

(a) can be observed in fig. 4 for $R_{a}$ and

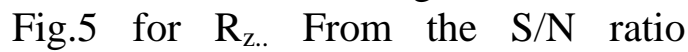
analysis in fig.4 (a), the optimum cutting variables for minimum $R_{a}$ value are found to be $180 \mathrm{~m} / \mathrm{min}$ of speed, $0.20 \mathrm{~mm} / \mathrm{rev}$ of feed rate and $1.5 \mathrm{~mm}$ or cut depth. Whereas, in fig 5(a) for minimum $R_{z}$ value of surface roughness, $150 \mathrm{~m} / \mathrm{min}$ of speed, $0.20 \mathrm{~mm} / \mathrm{rev}$ of feed rate and $1.5 \mathrm{~mm}$ of cut depth are the optimum values.

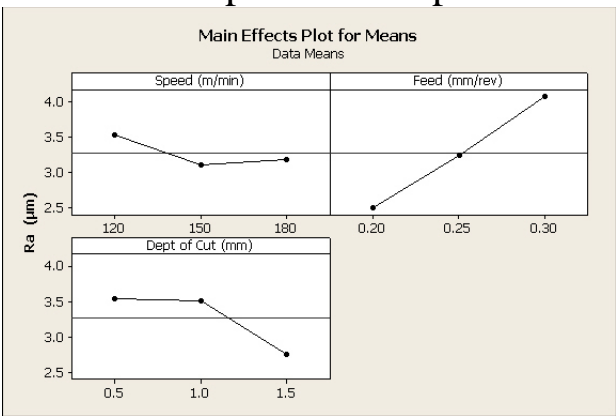

(b)

Fig.4. Main effect plots (a) Means of $S / N$ ratio for $R_{a}$ value (b) Effect of control factors on $R_{a}$ Value.

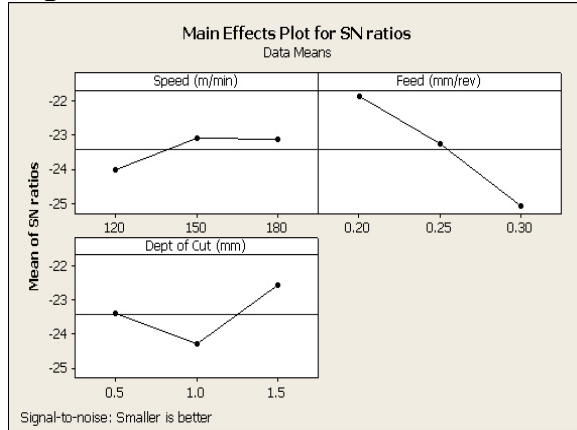

(a)

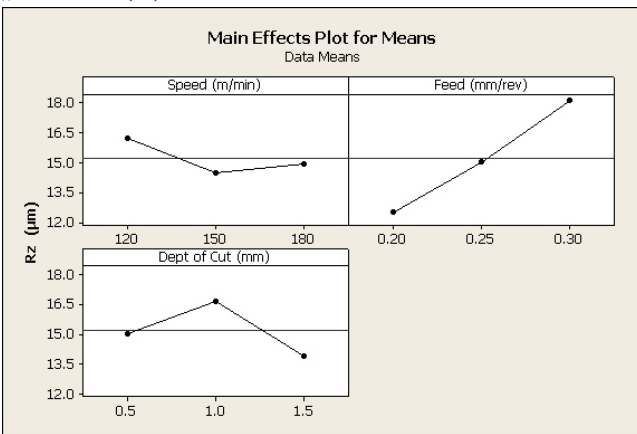

(b)

Fig.5. Main effect plots (a) Means of $S / N$ ratio for $R_{z}$ value (b) Effect of control factors on $R_{z}$ Value. 
From the effect of control factor plots of surface roughness for Ravalue in Fig.4(a), it can be seen that, as the cutting speed increaese from $120 \mathrm{~m} / \mathrm{min}$ to $150 \mathrm{~m} / \mathrm{min}$ there is decrease in Ra value, but further increase to $180 \mathrm{~m} / \mathrm{min}$ increaes the $R_{a}$ valuewhich may be, due to the presence of chatter at higher speed,formation of builtup edges during low cutting speeds and fluctuation in cutting force [5,7]. The surface roughness increases with increase in feed rate due to heat generation thereby tool wear hence, the higher surface rougness. Formation of chatter at higher feed rate may also be the cause for higher surface roughness. And also, as the cut depth increases the $R_{a}$ value decreases and same was also observed by Kaladhar et al.,[8] and this may be attributed by interactive effect of speed and cut depth.

From the figure $5(\mathrm{~b})$, same effect is observed for $R_{z}$ value as far as speed and feed are concerned for $R_{a}$ value but, for the cut depth, initially the $R_{z}$ value incresed with increase in cut depth and for further increase in cut depth suddenly there is a decrease in $R_{z}$ value.

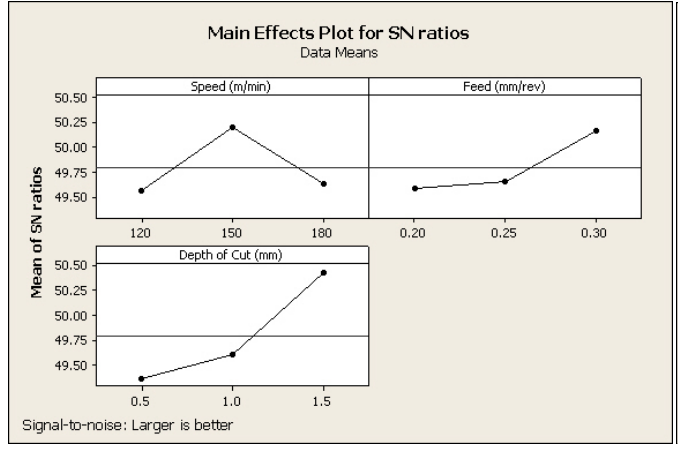

(a)
Analysis of surface Hardness.

Fig. 6 (a) shows the optimum values of cutting parameters for maximum surface hardness in consideration with $\mathrm{S} / \mathrm{N}$ ratio. According to this, $150 \mathrm{~m} / \mathrm{min}$ of speed, $0.3 \mathrm{~mm} / \mathrm{rev}$ of feed rate and $1.5 \mathrm{~mm}$ of cut depth are observed as optimum parameters. It can be observed from the fig.6 (b) that, increase in cutting speed from $120 \mathrm{~m} / \mathrm{min}$ to $150 \mathrm{~m} / \mathrm{min}$ increases the surface hardness. It is attributed by more time of penetration of cutting tool in to the work material during low speed which leads to more plastic deformation hence more work hardening. But further increase from 150 $\mathrm{m} / \mathrm{min}$ to $180 \mathrm{~m} / \mathrm{min}$ of speed reduced the surface hardness, may be due to increased surface deformation because of increased work hardening recovery due to rise in temperature. It can be seen from the fg.5(b) that, Increase in feed rate increases the surface hardness which is, because of increased heat generation and hence more work hardening. With increase in cut depth there is an increase in micro hardness of the turned surface. This is due to more strain hardening because of thermal softening of the material at high cut depth [21].

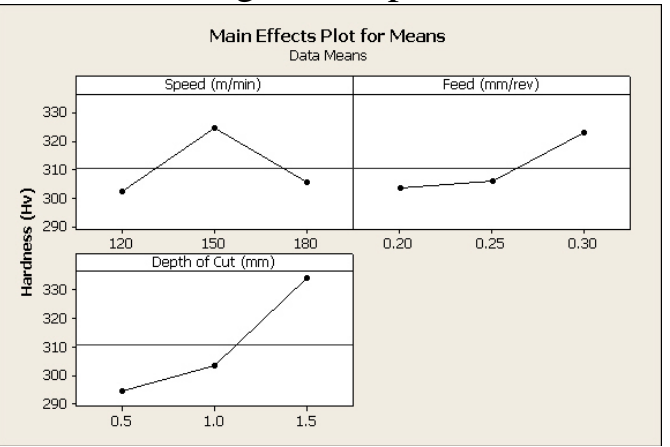

(b)

Fig.6. Main effect plots (a) Means of S/N ratio Hardness (b) Effect of control factors hardness.

Residual plots for cutting parameters normal probability plot of residuals for quality loss, plots of residual vs. fitted value, histogram and residual vs. the order of the data for $R_{a}, R_{z}$ and micro hardness, are shown in Fig. (7) (a), (b) and (c) respectively. According to residual plots it can be concluded that data are fairly normal and small deviations are observed for all the response parameters. It is also observed that, no significant unusual patterns for vs. fits, histograms and vs. orders present in the data. 


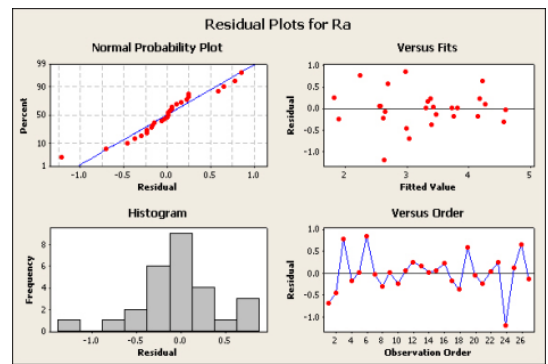

(a)

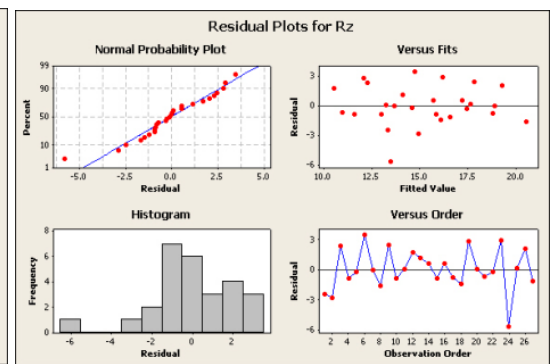

(b)

Fig.7. Residual Plots for (a) $\mathrm{R}_{\mathrm{a}}$ (b) $\mathrm{R}_{\mathrm{z}}$ and (c) Hardness (Hv)

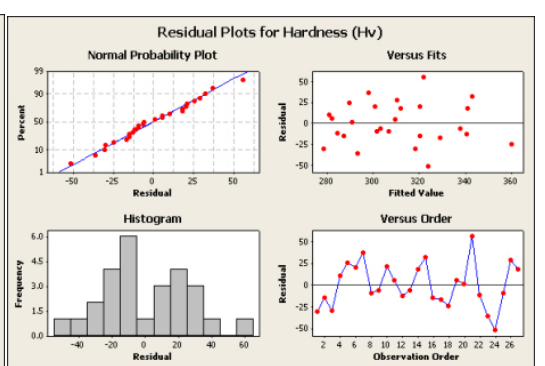

(c)

\section{Conclusion}

In the present experiment, Taguchi methodology was used for optimizing the cutting parameters during turning of Austenitic Stainless Steel 316 grade under dry cutting condition involving CVD coated TiN insert on $\mathrm{CNC}$ lathe. Optimum levels of speed, feed and cut depth were found so that minimized surface roughness and maximized surface hardness could be attained.

From the investigation it is evident that, feed rate is the principal parameter that contributes more on minimizing the surface roughness values of $R_{a}$ with $45.69 \%$ and $R_{z}$ with $41.87 \%$ of contribution. Cut depth and its interaction with speed have become next dominating factors after the feed rate for $\mathrm{R}_{\mathrm{a}}$ value with contribution of $18.74 \%$ and $17.14 \%$ respectively. The most optimal results for $R_{a}$ value were found for maximum cutting speed which was set at $180 \mathrm{~m} / \mathrm{min}$, feed rate of 0.2 $\mathrm{mm} / \mathrm{rev}$ and cut depth of $1.5 \mathrm{~mm}$. For minimum $R_{z}$ value of surface roughness optimum levels of cutting parameters were found to be 120 $\mathrm{m} / \mathrm{min}$ of speed, $0.20 \mathrm{~mm} / \mathrm{rev}$ of feed rate and $1.5 \mathrm{~mm}$ of cut depth.

The optimal levels for maximizing the surface hardness of the work specimen after dry turning were measured and it revealed that, joint effect of feed and speed has become the significant factor with $36.42 \%$ of contribution and is followed by cut depth with $25.23 \%$. Maximum hardness was noticed at greater feed rate and cut depth with moderate cutting speed. From the present study, with $150 \mathrm{~m} / \mathrm{min}$ of cutting speed, $0.3 \mathrm{~mm} / \mathrm{rev}$ of feed rate and 1.5 $\mathrm{mm}$ of cut depth have resulted with maximum surface hardness of $335 \mathrm{Hv}$.

\section{Acknowledgement}

We are very much grateful to Er. Adivesh Kenchreddy of Karnataka Original Equipment Manufacturers (KOEM), Gadag, India for permitting to carry out the experiments at their factory premises and for his valuable suggestions during accomplishment of experimental investigation.

\section{References:}

[1] Atul P. Kulkarni, Girish G. Kulkarni, Vikas G. Sargade. Dry turning of austenitic stainless steel using AiTiCrN coated insert produced by HPPMS technique.

International Conference on Design and Manufacturing 2013; 737-746.

[2] T. Akasawa a, H. Sakurai a, M. Nakamuraa, T. Tanaka b, K. Takano. Effects of free-cutting additives on the machinability of austenitic stainless steels. Journal of Materials Processing Technology2003; 143-144: 66-71.

[3] ZaferTekıner ,SezginYesilyurt.Investigation of the cutting parameters depending on processsound during turning of AISI 304 austenitic stainless steel. Materials and Design2004; 25:507-513. 
[4] IlhanAsilturk, SuleymanNeseli. Multi response optimization of CNC turning parameters via Taguchi method-based response surface analysis.

Measurement2012; 45: 785-794.

[5] IhsanKorkut, Mustafa Kasap, Ibrahim Ciftci, UlviSeker.Determination of optimum cuttingparameters during machining of AISI 304 austenitic stainless steel. Materials and Design2004; 25: 303 305.

[6] D. O'Sullivan, M. Cotterell. Machinability of austenitic stainless steel SS303 Journal of Materials Processing Technology2002; 124: 153-159.

[7] Ibrahim Ciftci. Machining of austenitic stainless steels using CVD multi-layer coated cemented carbide tools. Tribology International2006; 39: 565-569.

[8] M Kaladhar, K VenkataSubbaiah, Ch. ShrinivasRao. Determination of optimum process parameters during turning of AISI 304 Austenitic stainless steel using Taguchi method and ANOVA. International journal of Lean Thinking2012; 3: issue1.

[9] M. Anthony Xavior, M. Adithan.

Determining the influence of cutting fluids on tool wear and surface roughness during turning of AISI 304austenitic stainless steel.journal of materials processing technology2009; 2 0 9: 900-909.

[10] Rastee D. Koyee , Rocco Eisseler, Siegfried Schmauder. Application of Taguchi coupled Fuzzy Multi Attribute Decision Making (FMADM) for optimizing surface quality in turningaustenitic and duplex stainless steels. Measurement2009; 58: 375-386.

[11] D.Y. Jang a, T.R. Watkins, K.J. Kozaczek, CR. Hubbard, O.B. Cavin. Surface residual stresses in machined austenitic stainless steel. Wear1996; 194: 168-173.
[12] Swapnagandha S. Wagha, Atul P. Kulkarnib, Vikas G. Sargade. Machinability studies of austenitic stainless steel (AISI 304) using PVD cathodic arc evaporation(CAE) system deposited AlCrN/TiAlN coated carbide inserts.Procedia Engineering2013; 64: 907 $-914$.

[13] DilbagSingh . P. VenkateswaraRao. A surface roughness prediction model for hard turning process.Int $\mathbf{J}$ AdvManufTechnol 2007; 32: 1115-1124.

[14] M. Huseyin Cetin, Babur Ozcelik ,EmelKurama, ErhanDemirbas. Evaluation of vegetable based cutting fluids with extreme pressure and cutting parameters in turning of AISI 304L by Taguchi method. Journal of Cleaner Production2011; 19: 2049-2056.

[15] IlhanAsilturkHarunAkkus.Determining the effect of cutting parameters on surface roughness in hard turning using the Taguchi method. Measurement2011; 44: 1697-1704.

[16] Samir Khamel, NouredineOuelaa and KhaiderBouacha.Analysis and prediction of tool wear, surface roughness and cutting forces inhard turning with CBN tool. Journal of Mechanical Science and Technology2012; 26 (11): 3605-3616.

[17] D.I. Lalwani, N.K. Mehta, P.K. Jain. Experimental investigations of cutting parameters influence on cutting forces and surface roughness in finish hard turning of MDN250 steel. Journal of materials processing technology2008; 20 6: 167 179.

[18] M S Phadke. Quality Engineering using Robust Design. Prentice-Hall international Inc, Englewood Cliffs, New Jersey: 1989.

[19] P J Ross, Taguchi Techniques for Quality Engineering, McGraw-Hill, New York: 1996. 
[20] Minitab Inc., Minitab user manual version 16, Quality plaza, 1829 Pine hall road, state college, PA 16801-3008, USA: 2011.

[21] R S Pawade, Suhas S. Joshi, P K

Brahmankar.Effect of machining parameters and cutting edge geometry on surface integrity of high-speed turned inconel 718. International journal of machine tools \&manufacture 2008; 48: 1528. 